International Journal of Linguistics, Literature and Translation

ISSN: 2617-0299 (Online); ISSN: 2708-0099 (Print)

DOI: $10.32996 / \mathrm{ijllt}$

Journal Homepage: www.al-kindipublisher.com/index.php/ijltt

IJLLT

\title{
Semiotic Analysis of Joyce Kilmer's Poems
}

\author{
Emelyn Magsipoc Talibong \\ Assistant Professor IV, Mindanao State University-Integrated Laboratory School, Marawi City, Philippines
}

$\square$ Corresponding Author: Emelyn Magsipoc Talibong, E-mail: emelynmtalibong@gmail.com

\section{ARTICLE INFORMATION}

Received: 15 September 2021

Accepted: 03 October 2021

Published: 30 October 2021

DOI: 10.32996/ijllt.2021.4.10.20

\section{KEYWORDS}

Semiotic analysis, Denotation, Connotation, Poems, Joyce Kilmer

\section{ABSTRACT}

This study which is a semiotic analysis of the poems of Joyce Kilmer had discovered through the use of Barth's Denotation-Connotation Theory the use of both literal and non-literal meanings of some important recurring words in Kilmer's poems. The recurring words serving as leitmotifs were therefore subjected to semiotic analysis and interpretation. The study did explore, therefore, the signs (visual images in the poems) by giving the signifier and the signified of some word/s as signs. With the DenotationConnotation of the word, it even led the researcher to a new level of signified something higher in meaning than the two, connotative still. Moreover, the use of semiotic analysis of the poems even became a tool to= experience side benefits of the study - that is, giving a researcher a cue that Joyce Kilmer's poems revolved around nature, God as thematic content with emotion overflowing in the literary opuses. Thus, with the side benefits, the researcher was even led further to realize that the poet (Joyce Kilmer) belonged to the Romantic Era of the literary movement.

\section{Introduction}

The realm of semiotics has its place in spoken and written communications as it assigns meanings to signs that can be words, images, sounds, gestures, and objects. In this respect, literature as a form of written text is one object of semiotic study as it conveys lots of symbols, images, and even figures of speech that have meaning in themselves.

One of the literary genres that have inspired semioticians is poetry. This is so since poetry, though condensed speaks, a lot; the presence of images (which often are figurative, thus, are also symbols) with indirect, intricate meaning cannot be distanced from semiotic analysis and interpretation. Semiotics can be a powerful tool that reveals significant meanings of symbols in poetry. Efforts of meaning-making through rigorous analysis can be rewarding especially when the literary labor arrives at discovering valuable truths - often serving as an epiphany allowing us to suddenly feel something very important and respond to it effectively and resolve to apply that very important "something" to our lives.

How can we understand poetry and enjoy its meaning? According to Welleck and Warren (1976) in the understanding of meaning, a look at the sequence of image, metaphor, symbol, and myth is very important.

I must suppose that it is this understanding that stirs our pathos, moves us to logical responses, and causes us to muse over the golden truths dawning upon us and live up to these noble truths, practically.

This study, had thus, considered the poetry of Joyce Kilmer, an American poet-soldier. Kilmer though had not much gained prominence in his lifetime, yet, left a certain legacy in the vast field of literature through his poetry much more, through his worldcelebrated fait accompli -- his poem "Trees."

As such, semiotics and the poems of Joyce Kilmer are partnered as the former is much necessitated to understanding symbols in his poems especially analyzing and interpreting them. Poems with symbols that could stand for a hoard of realities and vicissitudes of life are construed to be of significant human experience.

Semiotics is then valued because of its contributing achievement to shedding light to sign analysis and interpretation in the many fields of semiotic studies, not to exempt the literary world. As Chandler (2006) points out, "Semiotics involves the study not only

Copyright: (c) 2021 the Author(s). This article is an open access article distributed under the terms and conditions of the Creative Commons Attribution (CC-BY) 4.0 license (https://creativecommons.org/licenses/by/4.0/). Published by Al-Kindi Centre for Research and Development, London, United Kingdom. 
of what we refer to as 'signs' in everyday speech but of anything which 'stands for something else'. In a semiotic sense, signs take the forms of words, images, sounds, symbols, gestures, and objects. Signs do not just 'convey' meanings, but constitute a medium in which meanings are constructed. Semiotics helps us to realize that meaning which is not passively absorbed but arises only in the active process of interpretation."

\title{
2. Literature Review
}

Some bits of review of literature is to follow that could possibly enlighten the present undertaking. Poetry is a literary work in verse writing of high quality, great beauty, a piece of art, with emotional sincerity or intensity, a graceful expression showing imagination and deep feeling with beautiful and elegant quality. It is a profound insight that enables a poet to idealize reality and to see the things or situations in a particular way, to express the feelings of his own accord, and to represent them in such a way as to delight the readers. It is the quality of great poetry through which the creeds and the system of human values are discussed that a reader may ultimately be enlightened and rejoiced. Poetry is also a good source of freeing somebody from ignorance, misdeeds, or evils while it inspires and encourages us; instills in us noble thoughts by dealing very much with the ways we live (Carter, 2004).

The descriptive definition above seems to offer no difficulty as poetry is considered a medium that enlightens and delights the reader can be a fulfillment of the Horatian twin purposes of poetry - that is, dulce et utile (sweet and usable). Thus, poetry affords literature or poetry lovers pleasure and usability of poetry. However, to read and understand poetry as quickly as we think is not that easy.

Accordingly, understanding the meaning or message in poetry is not that easy. With its brevity, it takes time for the readers to grasp easily what it wants to convey. Students often approach poetry like a puzzle that needs to be solved as quickly as possible. However, to find the deeper meaning of a poem, the reader needs to closely examine the imagery, the figurative language, the symbols, and the context of the poem (Hartless, http://penandthepad.com/find-meaning-poem-2282538.html)

Symbolism in poetry is one troubling experience of any avid and passionate reader. The use of symbols to signify ideas and qualities by giving them meanings that are different from their literal sense needs thorough analysis and interpretation. Generally, it is an object representing another to give it an entirely different meaning that is much deeper and more significant. What often makes symbols hard to understand is the shift of their meanings depending on the context they are used (https://literarydevices.net/s).

Poetry symbols when given meanings under semiotics should at least be taken into the two levels of meaning - denotative and connotative. 'Denotation' tends to be described as the definitional, 'literal', or meaning of a sign. In the case of linguistic signs, the denotative meaning is what the dictionary attempts to provide. For the art historian Erwin Panofsky, the denotation of a representational visual image is what all viewers from any culture and at any time would recognize the image as depicting. The term 'connotation' is used to refer to the socio-cultural and 'personal' associations (ideological, emotional, etc.) of the sign. These are typically related to the interpreter's class, age, gender, ethnicity, and so on. Signs are more 'polysemic' - more open to interpretation - in their connotations than their denotations. The consideration too, of how it is used in poetry - its context of use in the poem can lead to an interpretation of the meaning of sign or symbol either denotative or connotative (Panofsky 1970a, 513).

In view of denotation and connotation as our consideration of levels of meaning, let us consider the poem of William Blake, "The Sick Rose" with its few lines excerpted:

\author{
O rose, thou art sick \\ The invisible worm \\ That flies in the night \\ In the howling storm
}

The rose in the poem can never be taken in its literal sense. It is connotative of life and is in the bed of vivid joy (http://en.wikipedia.org/wiki/Semiotics). As Robert Frost said, "Poetry provides the one permissible way of saying one thing and meaning the other" which is expounded by Barnet $(1985$, p.103) that in poetry, words have their literal meaning but they can also be used that something other than the literal meaning is implied. The application of denotation and connotation, is thus, viewed as a contributing tool in the meaning-making of symbols revealed in poetry. However, the decision of finalizing the meaning of a poem symbol especially on connotation needs the assistance of syntagmatic context. This, according to Todorov (1982a) has to do with the nature of the means that make it possible to establish the indirect meaning: Reference to the immediate syntagmatic context (what was said previously, in what circumstances, etc.). 
Let us consider what Barthes (1977) is essentially trying to do in Rhetoric of the Image: To examine and understand the messages that images contain, and the extent to which they take part in creating an ideological worldview. That is to say, Barthes is asking how ideologically charged are images and transmit an educational message to society. In his essay, Barthes works along the lines of two theoretical distinctions: connotation and denotation, and the internal relations of the sign between the signifier and the signified. The signified, according to Barthes, has two levels of meaning: the denotational and the connotational. The denotation is the dictionary meaning of the sign/word and it detonates something in the real world. The connotation is the interpretative association that comes with the sign and is something that is culturally and context-dependent. For Barthes connotation is a higher meaning.

Moreover, connotation and denotation are often described in terms of levels of representation or levels of meaning - the notion

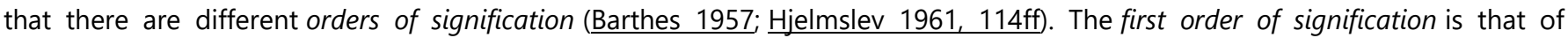
denotation: at this level, there is a sign consisting of a signifier and a signified. Connotation is a second-order of signification which uses the denotative sign (signifier and signified) as its signifier and attaches to it an additional signified. In this framework connotation is a sign which derives from the signifier of a denotative sign (so denotation leads to a chain of connotations). This tends to suggest that denotation is an underlying and primary meaning - a notion which many other commentators have challenged. Barthes himself later gave priority to connotation, and in 1971 noted that it was no longer easy to separate the signifier from the signified, the ideological from the 'literal' (Barthes 1977, 166). In passing, we may note that this formulation underlines the point that 'what is a signifier or a signified depends entirely on the level at which the analysis operates: a signified on one level can become a signifier on another level' (Willemen 1994, 105). This is the mechanism by which signs may seem to signify one thing but are loaded with multiple meanings.

In Saussurean analysis, which Barthes largely uses, the distinction between signifier and signified is crucial. The signifier is the image used to stand for something else, while the signified is what it stands for (a real thing or, in a stricter reading, a senseimpression). The signified sometimes has an existence outside language and social construction, but the signifier does not. Further, the relationship between the two is ultimately arbitrary. There are many different ways a particular signified could be expressed in language or different objects divided up. None of these ways is ultimately superior to the others (https://ceasefiremagazine.co.uk/in-theory-barthes-1/).

How about the role of visual images? Within semiotics, there is a debate between the amount to which the meaning of visual images can be shared and understood in themselves, or if their meaning is instead based on some prior verbal knowledge. As we have seen, in his essay Rhetoric of the Image, Roland Barthes argues that images, and their symbolic meanings, are always contingent upon the verbal text. Barthes claims that in order to reach the shared meaning, verbal text must enforce the visual with evidence.

Kress and Theo van Leeuwen (1996) in their book Reading Images also reveal that visual images can accomplish the same message and meaning that text can, but perhaps in a different way. Surrounded by symbols, images, and various signs, the human being has always strived to signify them and utilized them for communication. The meaning comes out of an interaction between the message and its reader (audience). While handling a text, one must consider not only its components but also the relationship between those components. All the impressions it has created and the techniques used for creating such impressions as well. When the images urge us to react, we are aware of their effect upon us, which is resulted from myths, ideologies, and connotations embedded in the images. Only through sophisticated analysis, the hidden meaning may be discovered. Visuals expedite and increase our level of communication. They increase comprehension, recollection, and retention. Visual clues help us decode texts and attract attention to information or direct attention increasing the likelihood that the audience will remember. Visual images enhance or affect emotions and attitudes. They engage our imagination and heighten our creative thinking by stimulating other areas of our brain (which in turn leads to a more profound and accurate understanding of the presented material). It is no secret that emotions influence decision-making.

\section{Methodology}

This study had to consider the poems of Joyce Kilmer which were subjected to textual-semiotic analysis, thus, followed a descriptive-interpretative research design in nature with some shades of text analysis and interpretation.

This study had to utilize the analytical-interpretive design to bring about the desired outcome of this study of course with the leading use of semiotic analysis inspired by Barthe's Theory of Denotation and Connotation.

The major research instruments or corpora used in this study were the poems of Joyce Kilmer. 
The gathering of data did not follow the traditional way - of administering research instruments but utilized the poems of Joyce Kilmer as data were inherent from the literary materials. Hence, data gathering sprang out from the semiotic analysis of the literary opuses studied.

\section{Results and Discussion}

The results of this study are presented in tables as follow:

Table 1. Denotation and Connotation as to Semiotic Analysis of the Poem, Love's A Lantern

\begin{tabular}{|l|l|l|l|}
\hline Word as a Sign & Denotation (Signifier) & Connotation (Signified) & $\begin{array}{l}\text { New Signified } \\
\text { (Connotation) }\end{array}$ \\
\hline Lantern & $\begin{array}{l}\text { - Something that is light. } \\
\text { - Can be a kerosene lamp } \\
\text { used during the journey at } \\
\text { night }\end{array}$ & $\begin{array}{l}\text { - Love of God as the } \\
\text { persona's guiding light }\end{array}$ & $\begin{array}{l}\text { Faith of the } \\
\text { persona in God that } \\
\text { wherever he goes, } \\
\text { journeys he knows } \\
\text { that God is with him } \\
\text { guiding him. }\end{array}$ \\
\hline
\end{tabular}

Table 1 reveals the results of the semiotic analysis of the poem, "Love's A Lantern". The word lantern from the title to the literary text has been repeated and somewhat the very sign that speaks for the signifier and the signified. As such, in the table, we can see that the lantern (a visual image) is the sign (word) in which by semiotic analysis is both a signifier (denotation) and signified (connotation).

As a sign of denotation, the lantern literally means something that is light; it can be a kerosene lamp used during the journey at night. However, beyond the dictionary level meaning, the lantern can symbolically mean the love of God as the persona's guiding light (connotation). With the denotation-connotation results, another signified of the lantern is arrived at -- Faith of the persona in God that wherever he goes, journeys he knows that God is with him guiding him.

What strikes the researcher in the first poem is the title itself, "Love's Lantern." He sees the image of a lantern from the perspective of denotative and connotative levels of meaning. Denotatively, the word lantern can be light or the lantern we have during the Christmas season. But, reading through the poem, he is able to contextualize the meaning of the visual image lantern to have its connotative significance. The image itself is a symbol as well.

What does the lantern symbolize then? We cannot immediately decide but there is a need to consider its context - how it is used in the poem by considering some of the words that are relational to it. Moreover, the principle of syntagmatic analysis may work. According to Todorov (1982), the syntagmatic context has to do with the nature of the means that make it possible to establish the indirect meaning and reference to the immediate syntagmatic context (what was said previously, in what circumstances, etc.) can be used as a basis to come up with lantern's indirect significance. Let us read the two opening lines of the poem: "Because the road was steep and long/And through a dark and lonely land" these lines suggest that he is on a journey.

The lines excepted may not still give us an ample idea of the indirectness of the lantern's meaning. Who knows he has a kerosene lamp with him? But the succeeding lines could be complementing our desired interpretation and meaning-making of lantern: "God set upon my lips a song/And put a lantern in my hand." These two lines are now helping us to see the deeper truth of the word. It is God who put a lantern in his hand - a strong communication that the lantern within the context of the poem is nonliteral.

Moreover, back to the title, Love's Lantern is metaphorical. Love is compared to a lantern, thus, allowing us to grasp that the love of God serves as his light. And God's love as his light is even brighter than any other literal lights in this world "O golden lights and lights like wine,/How dim your boasted splendors are./Behold this little lamp of mine;/ It is more starlike than a star!" Lastly, there can be a new signified that can be arrived at: Faith of the persona in God that wherever he goes or journeys his faith in God becomes history to light as to have faith is to trust God.

Going back to the third line, another symbol is introduced - "God set upon my lips a song" which again goes beyond the literal sense. The song here is connotative of happiness and God is his happiness despite the journey with "road so steep and long and through a dark and lonely land."

The poem preaches the message that God, for the poet (masked by the persona of the poem) is a powerful God who is his light and happiness. 
Table 2. Denotation and Connotation as to Semiotic Analysis of the Poem, Love's A Lantern

\begin{tabular}{|c|c|c|c|}
\hline $\begin{array}{l}\text { Word/s as a Sign or } \\
\text { Signs }\end{array}$ & Denotation (Signifier) & Connotation (Signified) & $\begin{array}{l}\text { New Signified } \\
\text { (Connotation) }\end{array}$ \\
\hline Tree & - A species of a tree & $\begin{array}{l}\text { - Object of admiration, } \\
\text { something of beauty }\end{array}$ & $\begin{array}{l}\text { - God's power is } \\
\text { shown through His } \\
\text { creation (tree) which } \\
\text { is matchless, } \\
\text { unsurpassable. }\end{array}$ \\
\hline Poem & $\begin{array}{l}\text { - A literary piece in verse; } \\
\text { a poem }\end{array}$ & $\begin{array}{l}\text { - Also an object of } \\
\text { admiration, something of } \\
\text { beauty as the persona } \\
\text { compares the tree and the } \\
\text { poem is compared in term }\end{array}$ & $\begin{array}{l}\text { - Poet's power } \\
\text { manifested in his } \\
\text { craft - a piece of } \\
\text { poetry, but his power } \\
\text { to write is just but a } \\
\text { minute detail of } \\
\text { God's power as the } \\
\text { poet can never } \\
\text { create a tree. }\end{array}$ \\
\hline
\end{tabular}

Table 2 discloses two important words that recur in the poem - tree and poem, in Trees". Denotatively, the tree (a sign which is a visual image) in the poem is really a literal tree (signifier) and the poem is too, a poem (signifier). Yet, connotatively both the tree and the poem can mean objects of admiration as the persona compare them in terms of their liveliness, they are possessing beauty (signified) worthy of admiration and appreciation. From the denotation-connotation results, another higher level, of signified is come up for both the tree and the poem - the tree connotatively has this new signified -- God's power shown through His creation (tree) which is matchless, unsurpassable by any man on earth;

while, the poem -- Poet's power manifested in his craft - a piece of poetry, but his power to write is just but a minute detail of God's power as the poet can never create a tree.

The second poem has to be read first and needs re-reading many times to get into the meaning of the poem, especially, its symbolism. The title seems to confuse the researcher as it has to be in plural form. But, let us try to get into it as we go along with our analysis with consideration of "trees" having a symbolic significance.

The opening lines in a couplet form: "I think that I shall never see/A poem lovely as a tree" is literally telling us that the poetpersona is comparing the loveliness of a poem to the loveliness of the tree. Here, the singularity of the tree can be considered a single tree that is the object of his powerful imagination.

He claims that the loveliness of the poem is the same as the tree yet, in the succeeding lines of couplets in a series he blows up the loveliness of the tree losing the comparative beauty or loveliness of the poem: "A tree whose hungry mouth is prest/Against the earth's sweet flowing breast." These two lines are a precursor to our analysis of why the tree is lovely. The instance of the use of personifications allows us to see that the tree is sipping water (hungry mouth) to a body of water (earth's sweet flowing breast). In the succeeding couplets must have started the beginning of his admiration to the tree: "A tree that looks at God all day,/And lifts her leafy arms to pray" can mean that the poet-persona admires the tree looking at God and lifting her leafy arms to pray as he finds the tree to be very healthy having gained nutrients from the water. All the other couplets that succeed continue to manifest the poet-persona's admiration (connotative too):

\section{A tree that may in Summer wear}

A nest of robins in her hair;

Upon whose bosom snow has lain;

Who intimately lives with rain.

The above couple of couplets still convey to us his unceasing admiration (connotation) moves another connotation of the tree allowing us to see it connotatively as a wonderful help for instance, as a home to the birds, the robins, and a shelter, an abode of the snow and a friend to the rain.

As he admires the tree, the poet-persona meaningfully ends the poem with a concluding couplet:

"Poems are made by fools like me,

But only God can make a tree." 
So beautiful are the two last lines that convey a sense of epiphany to him. What about? The use of the word "fool" simply is an understatement - "poems are made by fools like me" is an open verbal assertion that his power to create is finite - just a minute detail of God's power who creates a tree. The concluding couplet further reveals to us that he shows his humility before God - that he is just but inferior before his superior God.

Now, the completed textual semiotics of the poem was purposely decided for us to see what symbolism is present in the poem.

Based on Barthes' denotation-connotation principle, we can see that from the very beginning of the poem till the tenth line, the tree (singular) maintains its denotative levels of meaning. But in the twelfth line, the tree transforms into a symbolization of God's "unsurpassed power"(new signified).

On the account of the trees (plural) it may denote as "many trees" but looking at it within the context of the poem, trees connotatively is a symbol of nature that is part of the poet-persona's passion - his being a lover of nature and being a believer of God, the creator.

The poems subjected to semiotic analysis have led the researcher to work closely with the symbols used by the poet, Joyce Kilmer. Exploring their denotative and connotative levels of meaning leads the researcher to see more of the indirectness of their meanings. The use of context application/syntagmatic analysis has been a good help to arrive at the semiotics of the poem's symbols. From the analysis, the researcher is able to pinpoint poetic language of similar functions: The poems are producing images that are symbols in themselves and are further figurative language too. Say, for instance, the lantern, the song, and the tree/trees - all these are images that too are symbols and are metaphors. Moreover, the researcher through his readings remembers Sussane Langer's association of symbols to emotions which are made visible in the poems: song for happiness; lantern for the feeling of security, and tree/trees for the feeling of admiration and appreciation and of humility.

Via semiotics, the researcher is also able to see an emerging truth: central to Joyce Kilmer's poetry is the leitmotif that focuses on God and nature.

\subsection{The Side Benefits of the Semiotic Analysis}

Based on Tables 1 and 2, the researcher is able to gain side benefits from the study. He learns that Joyce Kilmer's poems revolved around the thematic ideas of God, nature and that there is an overflowing emotion conveyed in the literary opuses.

\section{Conclusion}

The use of semiotic analysis is able to address its objectives: 1) to bring to light the meanings of symbols in the poems covered. The analysis starts from getting into the literal meanings then to connotative meanings to arrive at the best interpretation and analysis of symbols, and 2 ) to get the side benefits of semiotic analysis. Based on the findings of the study, it is concluded that the poems of Joyce Kilmer have meaningful symbols that are revolving around nature and God. As to the benefits of using semiotic analysis, it is further concluded that one side benefit of it is the knowledge that the poems lead us to know that Joyce Kilmer belonged to the Romantic Period as his themes revolved around God and nature.

This study is a contribution to the existing literature as semiotic analysis is part of language and literary studies. As such, this study recommends that other poems of Joyce Kilmer be studied by future researchers to see if other poems also center on God and nature. opuses.

Conflicts of Interest: The author declares no conflict of interest.

\section{References}

[1] Barthes, R. (1977). The rhetoric of the Image: Image Music, Text, Ed. and trans. Stephen Heath, New York: Hill and Wang.

[2] Carter, R. (2004). Language and creativity: the art of common talk. London: Routledge.

[3] Hartless, K. (2011). What is Poetry? http://penandthepad.com/find-meaning-poem-2282538. HTML)

[4] Hjelmslev, L (1961): Prolegomena to a Theory of Language (trans. Francis J Whitfield). Madison: University of Wisconsin Press

[5] Joly, M. (1998). Introducere in analiza imaginii, Bucuresti, Ed. All

[6] Kress, G, (1995). Theo van Leeuwen.- Reading Images: The Grammar of Visual Design, London, Routledge.

[7] Lester P. M. (2002). Visual Communication: Images with Messages, Wadsworth Publishing co. Inc, 3rd revised ed.

[8] Lohisse, J. (2002). Comunicarea. De la transmiterea mecanica la interactiune. lasi, Ed. on sign/s.

[9] Todorov, T. (1982a). trans. Catherine Porter, Theories of the Symbol, Ithaca: Cornell University Press

[10] Willemen, P. (1994). Looks and Frictions: Essays in Cultural Studies and Film Theory. London: BFI/Bloomington, IN: Indiana University Press 


\section{APPENDIX A}

Love's Lantern (1)

Because the road was steep and long

And through a dark and lonely land,

God set upon my lips a song

And put a lantern in my hand.

Through miles on weary miles of night

That stretch relentless in my way

My lantern burns serene and white,

An unexhausted cup of the day.

O golden lights and lights like wine,

How dim your boasted splendors are.

Behold this little lamp of mine;

It is more starlike than a star!

\section{APPENDIX B}

Trees (2)

I think that I shall never see

A poem lovely as a tree.

A tree whose hungry mouth is prest

Against the earth's sweet flowing breast;

A tree that looks at God all day,

And lifts her leafy arms to pray;

A tree that may in Summer wear

A nest of robins in her hair;

Upon whose bosom snow has lain;

Who intimately lives with rain.

Poems are made by fools like me,

But only God can make a tree. 